\title{
Implementasi Pembelajaran Al-Qur'an Terhadap Perkembangan Nilai Agama dan Moral Anak Usia Dini
}

\author{
Siti Nurul Aprida ${ }^{1 凶}$, Suyadi ${ }^{1}$ \\ Pendidikan Islam Anak Usia Dini, Universitas Islam Negeri Sunan Kalijaga Yogyakarta, \\ Indonesia ${ }^{(1)}$ \\ DOI: $\underline{10.31004 / o b s e s i . v 6 i 4.1959}$
}

\begin{abstract}
Abstrak
Penerapan pembelajaran Al-Qur'an di TKQ Riyadlushshibyan bertujuan untuk menghasilkan anak usia dini menjadi anak yang qurani dan menghasilkan potensi anak-anak usia dini sebagai sumber daya manusia (SDM) berdasarkan Al-Qur'an. Penelitian ini bertujuan mengkaji bagaimana pelaksanaan pembelajaran Al-Qur'an terhadap perkembangan nilai agama dan moral (NAM) pada anak usia dini di TKQ Riyadlushshibyan. Penelitian ini memakai jenis penelitian deskriptif kualitatif dengan pengumpulan data yang dilakukan langsung di lokasi penelitian dan yang menjadi informan dalam penelitian ini adalah kelompok B (usia 5-6 tahun) yang berjumlah 13 orang. Cara untuk mengumpulkan datanya memakai teknik wawancara, observasi, serta dokumentasi. Hasil penelitian memperlihatkan bahwasannya dalam pelaksanaan pembelajaran Al-Qur'an pada perkembangan NAM anak usia dini menunjukan bahwa anak dapat mengetahui do'a pendek sehari-hari, anak mengetahui surat-surat yang biasa dibaca ketika shalat, anak mengetahui hari besar agama Islam, dan anak menunjukan perilaku sopan, hormat, peduli, toleransi, dan mampu menjaga kebersihan diri.
\end{abstract}

Kata kunci : pembelajaran al-qur'an; psikologi perkembangan; pendidikan anak usia dini.

\begin{abstract}
The application of Al-Qur'an learning at TKQ Riyadlushshibyan aims to produce early childhood children who are Qur'anic and produce the potential of early childhood children as human resources (HR) based on the Qur'an. The application of learning in this article is intended to examine how the implementation of learning the Qur'an on the development of religious and moral values (NAM) in early childhood at TKQ Riyadlushshibyan. This study used a qualitative descriptive research type with data collection carried out directly at the research site and the informants in this study were group B (aged 5-6 years) which consisted of 13 people. Ways to collect data using interview techniques, observation, and documentation. The results of the study show that in the implementation of Al-Qur'an learning in the development of early childhood NAM shows that children can know the daily short prayers, children know the letters that are usually read when praying, children know the big day of Islam, and Children show polite behavior, respect, care, tolerance, and are able to maintain personal hygiene.
\end{abstract}

Keywords: al-qur'an learning; developmental psychology; early childhood education.

Copyright (c) 2022 Siti Nurul Aprida, Suyadi

$\triangle$ Corresponding author :

Email Address : 21204031022@student.uin-suka.ac.id (Yogyakarta, Indonesia)

Received tanggal bulan tahun, Accepted tanggal bulan tahun, Published tanggal bulan tahun 


\section{PENDAHULUAN}

Kondisi belum tuntasnya pandemi Covid-19 di Negeri ini, ada tantangan yang berbeda serta amat serius dari pendidikan agama jika dibanding dengan pendidikan yang lainya. Pendidikan agama mempunyai ciri khas yang menekankan pada upaya melakukan transmisi Nilai Agama dan Moral (NAM) pada tindakan serta tingkah laku peserta didik didalam kehidupan sehari-hari. Pendidikan agama tak sekadar bertanggung jawab dalam hal menambah pengetahuan agama semata, akan tetapi juga tingkah laku dari peserta didik yang didasarkan pada nilai keagamaan yang baik. Hal ini diberlakukan pada semua tingkat pendidikan, terutama pada jenjang pendidikan anak usia dini (PAUD).

Anak usia dini adalah anak yang ada di usia rentan 0-6 tahun, dimana memiliki karakteristik unik, dan berbeda dari orang dewasa. Umur 0-6 tahun adalah masa awal hidup anak, sebab pada usia tersebut sedang terjadi proses yang sangat penting yaitu terjadinya pertumbuhan, perkembangan, penyempurnaan dan pematangan. Peristiwa tersebut sering dikenal dengan masa keemasan atau golden age. Mulyasa menyebutkan bahwasannya anak usia dini merupakan seseorang yang tengah menghadapi proses tumbuh kembang yang begitu cepat, pada masa usia dini ini bahkan sering dinamakan menjadi lompatan perkembangan (Mulyasa, 2012).

Dalam kehidupan sehari-hari, perkembangan seseorang berlangsung seumur hidup, diawali dengan masa konsepsi yaitu bertemunya sel ibu dengan ayah serta diakhiri ketika meninggal dunia. Yudrik Jahja mengungkapkan bahwa perkembangan memiliki proses pertambahan keberfungsian tubuh menjadi lebih kompleks merupakan akibat dari proses pematangan dalam pola yang teratur dan bisa diprediksi. Perkembangan terkait pada keberadaan proses diferensiasi dari sel, organ, serta jaringan tubuh, juga sistem organ yang mengalami perkembangan sedemikian rupa sehingga bisa melakukan fungsinya masingmasing (Jahja, 2011). Perkembangan individu sifatnya dinamis, berubahnya terkadang cepat ataupun lambat, hal ini terkait dengan satu ataupun lebih aspek perkembangan. Setiap individu memiliki proses perkembangan tidak selalu sama, apakah dalam waktunya ataupun kualitasnya.

Ada beberapa aspek yang tercakup pada perkembangan anak usia dini. Cakupan perkembangan anak usia dini yaitu perkembangan sosial, fisik, kemandirian, moral, bahasa, serta kognitif (Robert V. Kail, 2002). Mengacu pada Permendikbud No 146 tahun 2014 yang membahas mengenai Kurikulum 2013 PAUD yang tercantum pada pasal 5 menyatakan bahwasannya beberapa aspek pengembangan pada kurikulum PAUD meliputi: aspek nilai moral serta agama, fisik-motorik, kognitif, bahasa, sosial-emosional, serta seni (Kementerian Pendidikan Nasional, 2014).

Salah satu aspek yang tercantum di atas adalah beberapa aspek perkembangan, satu diantaranya yaitu terdapat aspek perkembangan NAM. Pendidikan moral untuk anak terkait erat dengan tingkah laku anak didalam hidup kesehariannya. Penanaman NAM di masa kanak-kanak menjadi sangat urgen yang harus dilakukan sebagai cara untuk menciptakan masyarakat yang bermartabat, bermoral, beradab serta agamis sejalan dengan berbagai nilai yang Islam ajarkan. Di sisi lain, proses mengembangkan NAM juga sangatlah diperlukan dalam upaya perbaikan terhadap keadaan sebuah negara. Untuk menghadapi bermacam masalah yang terdapat di negeri ini, pendidikan prasekolah berperan amat penting untuk mengejar dan berkontribusi dalam menanamkan NAM pada anak-anak Indonesia.

Suyadi berpendapat bahwa lembaga pendidikan sekolah memegang peranan yang begitu berarti dan strategis bagi pengembangan kepribadian siswa. Sekolah merupakan sarana penyebarluasan nilai-nilai moral yang mungkin belum terwujud dalam keluarga atau masyarakat. Semua pengalaman yang dimiliki anak-anak di sekolah merupakan program yang sangat efektif untuk membentuk kepribadian mereka (Suyadi, 2013). Terutama pada tingkat perkembangan prasekolah dan landasan yang kokoh pada tahap operasional tertentu, anak akan belajar banyak dari apa yang dilihatnya. Dengan perilaku meniru ini, 
peran guru sebagai pendidik mutlak diperlukan. Dengan demikian, tugas guru adalah bagaimana keduanya berperan sebagai panutan dan menciptakan suasana kelas dan sekolah yang kondusif, serta sebagai bentuk penguatan bagi pertumbuhan dan perkembangan karakter yang baik pada peserta didik.

Pendidikan yang diperuntukkan anak usia dini merupakan suatu upaya dalam rangka memberikan stimulus, mengasuh, memberikan bimbingan, serta mengarahkan anak pada aktivitas belajar mengajar yang dapat memunculkan suatu keterampilan serta kemampuan pada anak dalam berbagai hal. Proses belajar mengajar yang disampaikan pada anak merupakan bentuk stimulus yang diberikan oleh pendidik kepada peserta didik yang diharapkan terus memberi perhatian pada ciri-ciri yang ada di masing-masing tahap perkembangan anak.

Lebih lanjut pada UU Tahun 2003 mengenai Sisdiknas Bab 1 Pasal 1 Ayat 14 ditegaskan bahwa PAUD adalah sebuah upaya membina yang diberikan pada anak semenjak dilahirkan hinga mencapai umur enam tahun yang dilaksanakan dengan memberikan stimulus pendidikan sebagai upaya menunjang tumbuh kembang anak dalam aspek jasmani ataupun rohani sehingga anak mempunyai kesiapan untuk masuk ke jenjang pendidikan selanjutnya (Nasional, 2003). PAUD adalah salah satu wujud penyelenggaraan pendidikan yang titik beratnya adalah untuk meletakkan dasar kearah tumbuh kembang fisik yaitu mengkoordinasikan motorik kasar serta halus, kecerdasan yaitu perilaku serta sikap beragama, berbahasa serta komunikasi yang disesuaikan dengan keunikan serta tahapan perkembangan anak usia dini lalui.

Dalam kehidupan seorang muslim sehari-hari tentu tak dapat lepas dari nasehat serta apa yang diajarkan oleh Al-Qur'an, sebab sesungguhnya Al-Qur'an adalah panduan hidup dan rahmat bagi seluruh alam, khususnya untuk semua insan yang hidup di bumi ini. Karenanya sesosok muslim wajib belajar serta mengamalkan Al-Qur'an, serta mengimplementasikan berbagai hukum didalamnya yang berlaku dalam realitas hidup. Agar dapat memposisikan Al-Qur'an menjadi pedoman hidup, tentu perlu dimulai dengan mampu membaca setiap huruf yang ada didalam Al-Qur'an. Aktivitas tersebut harus dijadikan bagian integral dari kehidupan seorang Muslim, yang kemudian di implementasikan dalam kehidupan, tidak ada hari tanpa baca Al-Qur'an.

Penggunaan basis Al-Qur'an dalam proses pembelajaran dianggap sangat urgent untuk diberikan kepada anak sejak usia dini sebagai upaya untuk membentuk anak agar memiliki kepribadian yang Islami (berakhlak mulia). Hal tersebut sejalan dengan dengan penelitian yang telah dilakukan (Hidayat, 2017), bahwa fungsi Al-Qur'an dalam psikologi agama dan neurosains dapat dapat membentuk karakter dan perkembangan anak pada usia dini. Oleh karena itu, di dunia pendidikan Islam, terkhusus pada jenjang PAUD, perlu diajarkan kepada anak mengenai Al-Qur'an sebagai pedoman hidupnya dengan pengenalan mengenai dasar-dasarnya, agar dikemudian hari anak tidak terjerumus pada hal yang buruk.

Berdasarkan uraian diatas dapat diketahui bahwa pelaksanaan pembelajaran AlQur'an terhadap perkembangan NAM anak menjadi sangat penting untuk dilaksanakan, karena hal tersebut mempunyai banyak manfaat terhadap pertumbuhan dan perkembangan anak (Pangastuti, 2017). Untuk itu, penelitian ini bertujuan untuk memperoleh informasi mengenai pelaksanaan pembelajaran Al-Qur'an terhadap perkembangan nilai agama dan moral anak usia dini, khususnya pada anak usia 5-6 tahun yang dituangkan dalam rumusan masalah yaitu bagaimana implementasi pembelajaran Al-Qur'an terhadap perkembangan NAM anak usia dini.

\section{METODOLOGI}

Penelitian dalam kajian ini memakai metode deskriptif kualitatif yang bertujuan untuk mendeskripsikan serta mengungkap fakta apa adanya yang terjadi di lokasi penelitian tentang penerapan pembelajaran Al-Quran pada anak usia dini yang berada di Taman 
Kanak-Kanak Qur'an (TKQ) Riyadlushsibyan dalam upaya mengembangkan aspek Nilai Agama dan Moral (NAM). Cara mengumpulkan datanya diproses melalui penggunaan teknik wawancara, observasi, serta dokumentasi. Peneliti mengamati aktivitas pembelajaran secara langsung di lokasi penelitian. Wawancara dilakukan kepada guru kelas sekaligus kepada Kepala Sekolah TKQ Riyadlushshibyan. Sedangkan studi dokumentasinya dilakukan dengan cara mengambil foto-foto saat kegiatan pembelajaran berlangsung, dan dokumen yang relevan yang ada di Taman Kanak-Kanak Qur'an (TKQ) Riyadlushsibyan. Penelitian ini dilakukan kepada anak yang berada di kelompok B (usia 5-6 tahun), dengan jumlah 13 orang anak yang terdiri dari 6 anak laki-laki, dan 7 anak perempuan, dalam rentan dua minggu pada pertengahan bulan September 2021. Proses menganalisis data yang diproses pada penelitian ini yaitu melalui cara menganalisis kasus tunggal yakni diawali melalui penentuan subjek yang akan diteliti, kemudian dilanjutkan dengan menentukan sumber data penelitian, mengumpulkan kemudian menganalisisnya, mereduksi data seta menyimpulkan dan menyusun hasil penelitian tentang implementasi pembelajaran $\mathrm{Al}$ Qur'an terhadap aspek perkembangan nilai agama dan moral (NAM) pada anak usia dini (PAUD) khususnya anak berusia 5-6 tahun. Secara lebih terperinci pada gambar 1 adalah bagan tahap-tahap penelitian yang dilakukan oleh peneliti.

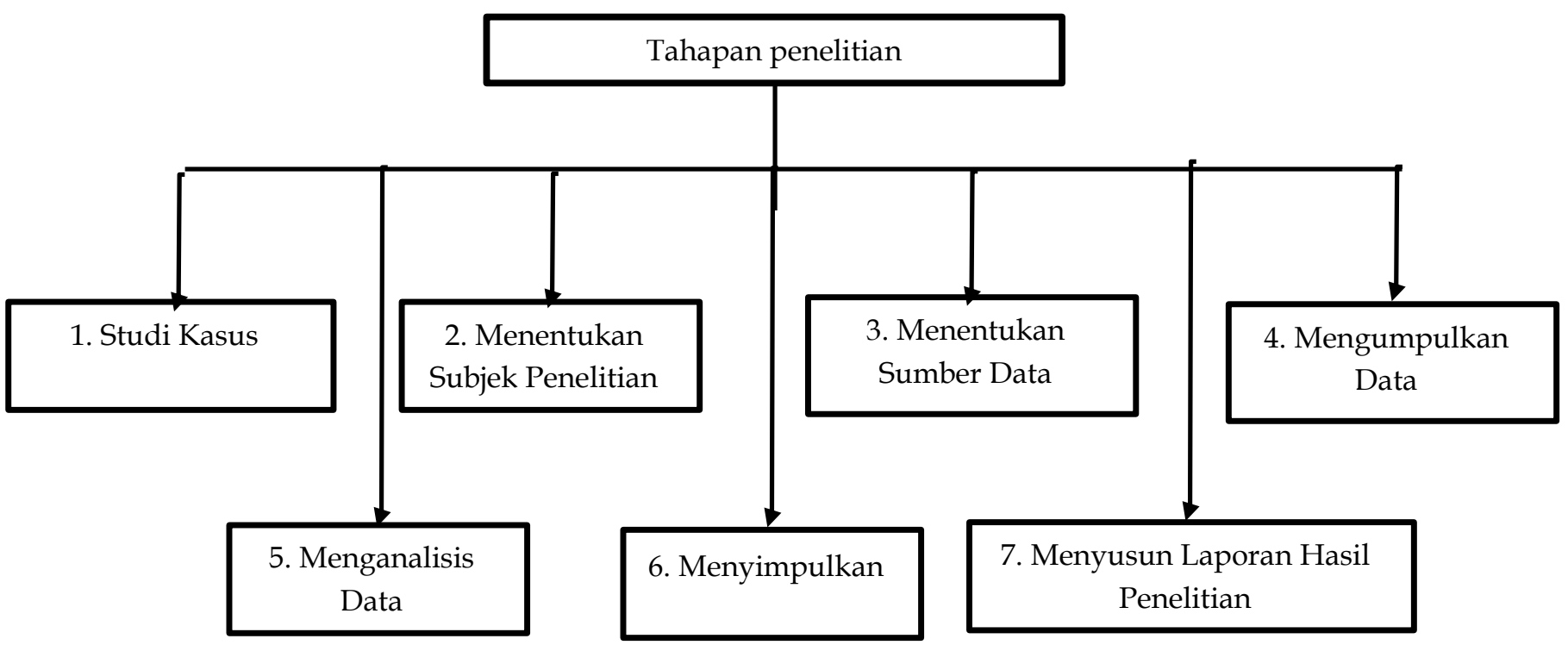

Gambar 1. Tahap-tahap Penelitian

\section{HASIL DAN PEMBAHASAN}

Didasarkan pada hasil analis dan pembahasan melalui wawancara, pengamatan, serta dokumentasi yang sudah dilaksanakan di Taman Kanak-Kanak (TKQ) Riyadlushsibyan dalam proses pembelajaran didapatkan hasil bahwa TKQ Riyadlushsibyan merupakan Taman Kanak-Kanak (TK) berbasis Al-Qur'an pertama yang berlokasi di Kabupaten Lebak, Banten. Proses pembelajaran Al-Qur'an di TKQ Riyadlushshibyan dilakukan tiap hari selama pembelajaran, kecuali hari jum'at. Proses pembelajaran Al-Qur'an dilakukan disetiap kegiatan pembelajaran dimulai ketika anak datang ke sekolah pada jam 07:30 sampai dengan penutup.

Di TKQ Riyadlushsibyan, pada proses pembelajaran Al-Qur'annya, pihak sekolah mengembangkan proses belajar mengajar yang melibatkan tiga kemampuan yaitu kemampuan membaca, menulis, serta menghafal Al-Qur'an sejak dini. Pengembangan kemampuan baca Al-Qur'an di TKQ Riyadlushshibyan dilakukan melalui metode Iqro yang dimulai dengan cara mengenalkan huruf hijaiyah secara sederhana, membedakan antar huruf hijaiyah dengan huruf hijaiyah yang lainya dan membedakan panjang pendek masing-masing huruf. Metode Iqro ini cukup efektif dalam menjadikan anak menjadi mampu, untuk 
membaca Al-Qur'an secara baik (Srijatun, 2017). Pengembangan kemampuan menulis AlQur'an di TKQ Riyadlushshibyan dilakukan dengan cara menebalkan huruf yang samar, dan mencontoh huruf yang sudah dibuat oleh guru. Kemampuan menulis huruf hijaiyah ini sangat penting bagi perkembangan anak (Ardin et al., 2020). Kemampuan menghafal AlQur'an di TKQ Riyadlushshibyan dikembangkan oleh TKQ Riyadlushshibyan dengan mengulang-ulang ayat yang ingin dihafal dengan nada yang khas secara bersama-sama, yang kemudian guru memberi pemahaman dan penjelasan mengenai ayat yang dihafal tersebut. Metode menghafal yang dilakukan secara bersama-sama ini biasa disebut dengan metode ya baba (Nurkhaeriyah., 2019).

Implementasi proses belajar mengajar Al-Qur'an yang dilakukan di TKQ Riyadlushshibyan dimulai dengan beberapa tahap meliputi; perencanaan pembelajaran, pelaksanaan pembelajaran, dan penilaian pembelajaran. Perencanaan pembelajaran yang dibuat disusun berdasarkan identitas program, tema, materi, sumber belajar, media, dan alat \& bahan pembelajaran. Kegiatan pembelajaran yang dilakukan terdiri dari kegiatan awal, kegiatan inti, dan penutup. Langkah terakhir adalah penilaian/evaluasi pembelajaran (Fitri, 2019).

Pertama proses perencanaan, prencanaan merupakan sebuah rangkaian persiapan yang akan dilakukan untuk mencapai suatu tujuan (Lestariningrum, 2017). Perencanaan pembelajaran merupakan langkah pertama yang dibuat oleh guru TKQ Riyadlushshibyan sebelum melaksanakan pembelajaran pada setiap hari untuk mencapai tujuan yang diharapkan, serangkaian persiapan tersebut sering dikenal dengan rencana pelaksanaan pembelajaran harian (RPPH) (Primayana, 2019). Komponen-kompenen yang terdapat didalam perencanaan pembelajaran ditulis didalam sebuah kertas atau buku sekolah yang terdiri dari: identitas program, tema, materi, sumber belajar, media, alat \& bahaan, kegiatan pembelajaran (kegiatan awal, kegiatan inti, dan penutup), dan penilaian atau evaluasi pembelajaran (Limbong et al., 2019).

Kedua, pelaksanaan pembelajaran. Pelaksanaan pembelajaran terdiri dari kegiatan pembuka, kegiatan inti, dan penutup (Kebudayaan, 2018). Kegiatan awal atau pembukaan yang dilakukan di TKQ Riyadlushshibyan dimulai secara klasikal atau dilakukan secara bersama-sama dengan seluruh siswa baik kelompok A maupun kelompok B, dengan cara anak berbaris secara bersama-sama diluar kelas. Pada kegiatan pembuka ini guru membuka kegiatan pada hari tersebut dengan mengucapkan salam, menanyakan kabar anak-anak, menanyakan hari ini hari apa, menanyakan anak sudah sarapan atau belum, kemudian dilanjutkan dengan berdo'a sebelum belajar, setelah itu anak bersama-sama bernyanyinyanyi, bertepuk-tepuk, dan mengulang hafalan yang telah dihafal hari kemarin. Setelah semua ritual pembukaan dilakukan, anak mulai masuk ke dalam kelas dengan cara berbaris memanjang seperti kereta, dalam barisan tesebut anak mengulang hafalan secara individu kepada guru/wali kelas kelompoknya tetapi kadang kegiatan tersebut diganti oleh guru dengan memeriksa setiap jari anak, apakah terdapat kuku yang panjang dan kotor atau tidak. Kegiatan pembuka ini (gambar 2) dilakukan sebelum anak masuk ke dalam kelas dan dilakukan selama kurang lebih 30 menit.

Setelah aktivitas pembuka selesai, langkah selanjutnya masuk pada aktivitas inti. Dalam aktivitas inti, dimulai oleh pendidik didalam kelas dengan cara bersama dengan peserta didik atau klasikal seperti pada kegiatan pembuka tadi, karena pada kegiatan ini anak akan melaksanakan shalat dhuha berjamaah (gambar 3), pada kegiatan inti ini dibuka dengan menanyakan kepada anak apakah anak membawa sesuatu yang diperintahkan oleh guru dihari kemarin atau tidak, karna pada hari tersebut anak akan melaksanakan shalat duha berjamaah, kemudian dilanjutkan dengan anak mempersiapkan dirinya untuk shalat dhuha bersama-sama. Setelah semuanya siap, guru menanyakan kembali kepada anak tentang shalat dhuha ini dilakukan berapa jumlah rakaatnya, manfaat dari shalat dhuha ini apa, dan bagaimana niat shalatnya. Setelah itu anak baru memulai shalatnya, dibimbing oleh 3 guru. Pada rakaat pertama anak membaca surat Al-Kaafirun, selanjutnya pada rakaat kedua anak 
membaca surat Al-Ikhlas. Setelah melaksanakan shalat dhuha berjama'ah, dilanjutkan dengan zikir setelah shalat kemudian disusul dengan membaca do'a bersama-sama seperti do'a shalat dhuha, do'a untuk kedua orang tua, kemudian anak dibiasakan untuk berdo'a sesuai dengan keinginanya sendiri-sendiri, anak diajarkan untuk meminta kepada Allah mengenai keinginanya, (ada yang menginginkan sepedah, ada yang menginginan tas baru, dan lain sebagainya). Setelah anak selesai berdo'a kemudian ditutup dengan do'a sapu jagat. Setelah semua rangkaian shalat dhuha selesai dilaksanakan, kemudian dilanjutkan dengan kegiatan mengaji (gambar 4), pada kegiatan ini anak dibagi menjadi tiga kelompok dan masing-masing kelompok tersebut didampingi oleh satu orang guru. Di dalam kelompok ini, anak baris memanjang seperti kereta kemudian bergantian antara satu dengan yang lainya untuk mengaji Iqro' satu persatu kepada guru. Setelah selesai mengaji, langsung dilanjutkan dengan mengulang hafalan yang telah dihafal oleh anak (gambar 4).

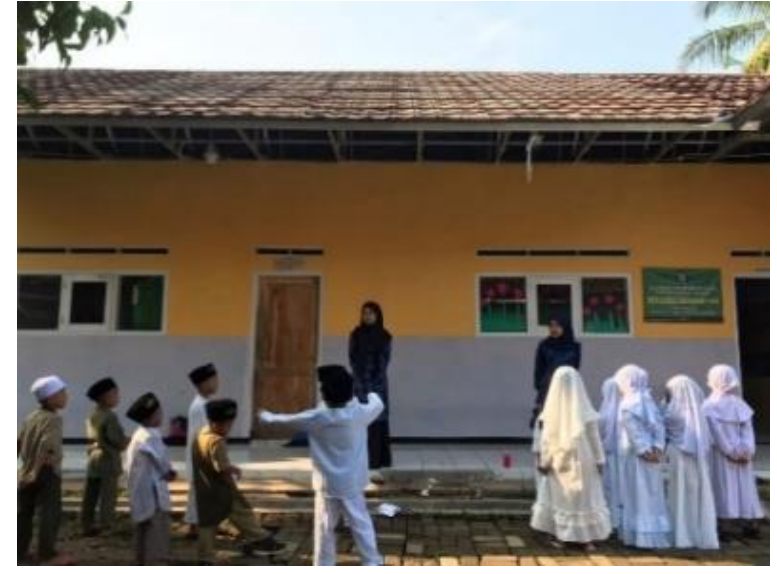

Gambar 2. Kegiatan pembukaan peserta didik TKQ Riyadlushibyan

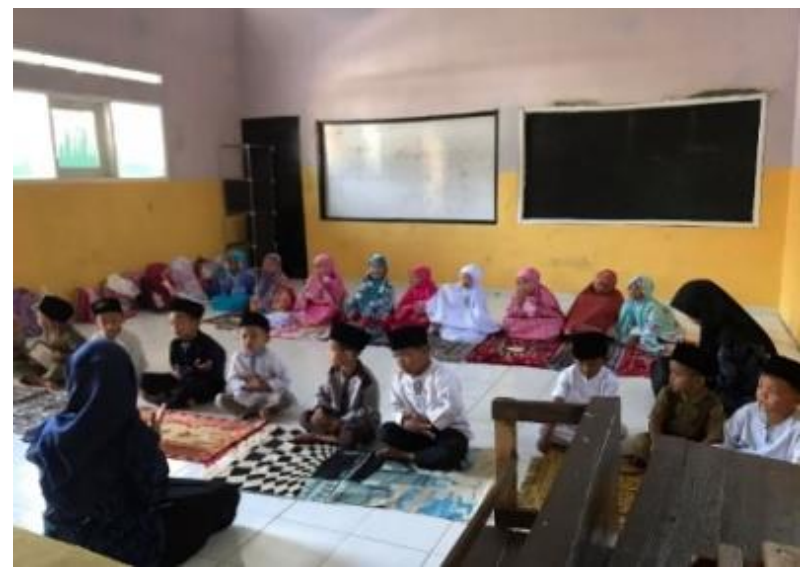

Gambar 3. Anak melaksanakan shalat duha berjamaah
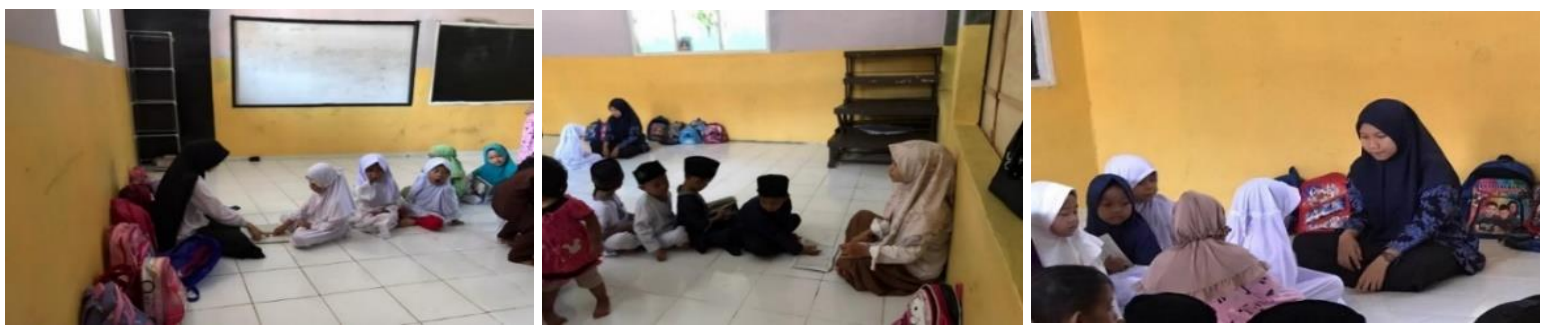

Gambar 4. Kegiatan mengaji dan mengulang hafalan Al-Qur'an

Kegiatan penutup. Pada kegiatan penutup ini dimulai dengan masuk kembali kedalam kelas setelah anak beristirahat selama kurang lebih 30 menit. Pada kegiatan ini, anak masuk kedalam kelasnya masing-masing tidak sama seperti pada kegiatan pembuka dan kegiatan inti tadi. Pada kegiatan penutup ini guru menanyakan kepada anak bagaimana perasaanya pada hari ini, kegiatan apa saja yang telah dilakukanya, dan menanyakan kesiapanya untuk menambah hafalanya sebanyak 1 ayat. Ketika guru merasa anak sudah siap untuk menambah hafalan baru, kemudian guru memulai dengan membaca "Bismillahirahmanirrahim, yatuufu "alaihim wildaanum mukhaladuun" dengan nada khas yang ada di Riyadlushshibyan, setelah membacakan satu ayat baru yang ingin dihafal selanjutnya guru mengulang-ulang satu ayat tersebut secara bersama-sama dengan seluruh anak kelompok B. Setelah selesai menambah hafalan baru kemudian guru mengajak anak untuk bersiap pulang, sebelum pulang biasanya guru mengajak anak untuk main tebak-tebakan, pertanyaan yang dilontarkan guru kepada anak tidak jauh dari Al-Qur'an yang telah diajarkan, tujuanya agar menguatkan ingatan anak sekaligus agar guru mengetahui tingkat pemahaman peserta didik. 
Ketiga penilaian atau evaluasi, evaluasi adalah cara untuk mengukur hasil dari aktivitas belajar anak yang dilaksanakan selama kegiatan belajar mengajar, dimulai dari aktivitas pembukaan, inti, hingga penutup (Wahyuni et al., 2018). Penilaian kegiatan belajar yang dilakukan di TKQ Riyadlushshibyan menggunakan pendekatan penilaian ceklis dan catatan pribadi yang ditulis oleh guru. Penilaian yang dilakukan tersebut merupakan penilaian dari seluruh proses yang telah dilewati dan hasil belajar pada hari tersebut untuk mengukur tingkat pencapaian berdasarkan fakta apa adanya yang terjadi.

Perkembangan nilai agama dan moral (NAM) pada anak usia dini bisa didefinisikan menjadi perubahan psikis yang siswa alami kaitannya dengan kemampuannya dalam memahami serta menerapkan tingkah laku yang berkesusuaian apa yang diajarkan oleh agama yang dipeluknya (Nabilah, 2019). Anak merupakan manusia kecil yang mempunyai potensi yang perlu dikembangkan dan mempunyai ciri-ciri yang tidak sama dengan manusia dewasa. Rentang umur anak usia dini adalah 0-6 tahun yang mana pada usia tersebut proses tumbuh kembang anak sedang ada di masa yang cepat selama rentang kehidupan manusia (Nabil, 2017). Di masa tersebut terkhusus ketika berusia 4-6 tahun pada anak terjadi masa peka, yang mana anak memiliki sensitivitas lebih dalam menerima bermacam rangsangan. Masa peka merupakan saat dimana terjadi pematangan berbagai fungsi fisik serta psikis yang senantiasa siaga dalam memberikan respon terhadap rangsangan dari lingkungan sekitar anak (Didik Supriyanto, 2015).

Pembelajaran Al-Qur'an pada anak usia dini yang telah dilakukan di TKQ Riyadlushshibyan merupakan sebagai usaha untuk memberikan stimulasi, bimbingan, pengasuhan serta pemberian aktivitas belajar mengajar yang dapat menghasilkan keterampilan serta kemampuan anak (Julianto, 2020). Adapun pengertian dari Al-Qur'an sendiri merupakan firman Allah落 yang telah diwahyukan pada Nabi Muhammad dengan sejumlah cara yang Allah ${ }^{\underline{w}}$ kehendaki yang di dalamnya termuat berbagai hukum Islam serta tuntunan untuk manusia demi tercapinya kebahagiaan hidup lahir dan batin, di dunia maupun akhirat (Srijatun, 2017).

Menurut Peraturan Menteri Pendidikan dan Kebudayaan Republik Indonesia nomor 146 tahun 2014 dalam indikator pencapaian perkembangan anak pada poin yang berhubungan dengan perkembangan agama dan moral menyebutkan bahwa anak yang berusia 5-6 tahun diharapkan sudah mampu (1) Mengenal agama yang dianutnya (misal: anak mengetahui seorang muslimah harus menutup aurat); (2) Membiasakan diri untuk beribadah (misal: shalat, dan puasa); (3) Berperilaku sesuai dengan ajaran agama yang dianutnya (misal: bersikap sopan dan sabar); (4) Menjaga kebersihan diri dan lingkungan; (5) Mengetahui hari besar agama; dan (6) Menghormati atau toleransi terhadap agama lain (Kementerian Pendidikan Nasional, 2014).

Berdasarkan hasil penelitian yang telah dilakukan di Taman Kanak-Kanak Qur'an (TKQ) Riyadlushsibyan didapatkan hasil bahwa, pertama; anak sudah mengetahui agama yang dianutnya dan anak sudah mampu melafalkan beberapa do'a pendek yang dianjurkan dibaca dalam memulai atau mengakhiri kegiatan (misalnya: do'a sebelum serta sesudah belajar, do'a sebelum serta setelah makan, do'a ketika akan memasuki kamar mandi serta setelah keluar dari kamar mandi, do'a keluar rumah, do'a untuk kedua orang tua, dan do'a sapu jagat). Kedua; TKQ Riyadlushshibyan mempunyai salah satu program unggulan yaitu, program shalat sunnah dhuha setiap hari kamis, hal tersebut merupakan sebuah bentuk usaha untuk membiasakan anak beribadah sejak dini yang dilakukan oleh pihak sekolah. Ketiga; pada saat melakukan pengamatan anak menunjukan perilaku yang sesuai dengan ajaran agama yang dianut oleh anak yaitu, pada saat anak datang dan mulai memasuki kelas, anak bersalaman kepada guru dan juga peneliti. Perilaku tersebut menunjukan perilaku yang sopan dan hormat kepada orang yang lebih tua, kemudian pada saat pembelajaran dimulai anak menunjukan perilaku peduli terhadap temanya dengan cara berbagi dan menggelar sajadah untuk shalat dhuha secara bersama-sama dengan temanya. Keempat; anak sudah mengetahui dan mampu menjaga kebersihan dirinya dan juga lingkungan (seperti: pada saat kegiatan 
pemeriksaan kuku, didapatkan hasil bahwa mayoritas kuku anak bersih, dan anak sudah memahami dan mampu membuang sampah pada tempatnya). Kelima; anak mengetahui hari besar agama (misalnya: hari raya idul adha, serta idul fitri). Keenam; anak memahami dan toleransi terhadap agama lain dengan bentuk anak mengetahui ada kitab-kitab lain selain AlQur'an dan anak mengetahui bahwa setiap tanggal 25 Desember merupakan hari besar agama lain. Berdasarkan pemaparan tersebut bisa ditarik kesimpulan bahwasannya perkembangan NAM anak sudah mengalami perkembangan sesuai dengan standar yang ada didalam Permendikbud No. 146 Tahun 2004.

NAM yang telah dimiliki setiap anak akan mampu menghantarkan kepada kebeningan dan keindahan hidup (Rahman, H., Rita Kencana, 2020). Nilai-nilai yang terkandung tersebut perlu ditanamkan kepada anak sejak dini sebagai bekal untuk menghadapi tantangan hidup yang ada di zaman berikutnya. Tahap perkembangan moral agama yang cukup terkenal adalah menurut pandangan Theory of faith dari James Fowler. Menurut James Fowler anak berusia 5 sampai 6 tahun ada di tahapan pertama yakni Intuitiveprojective faith, pada tahapan ini anak belum terlalu paham akan wujud Tuhan yang dianggap gaib. Anak berimajinasi tentang Tuhan dengan arahan orang dewasa, dalam hal ini guru. Selain itu, anak juga dapat menemukan gambaran mengenai perilaku baik dan jahat (Fowler \& Dell, 2004). Adapun faktor yang mempengaruhi NAM pada anak khususnya pada anak berusia 5 sampai 6 tahun termasuk dalam faktor perkembangan awal yang mana pada anak usia ini berada dalam masa kritis yang dapat menjadi penentu perkembangan dan akan menemukan perbedaan pertumbuhan serta perkembangan diantara seorang anak dengan anak lainnya. Faktor perkembangan awal dipengaruhi oleh faktor keluarga, cara mendidik anak, emosional, serta stimulus dan menyenangkan atau tidaknya lingkungan sosial sekitar anak (Rahman, H., Rita Kencana, 2020).

Lingkungan yang menyenangkan anak, ketika anak mempunyai hubungan yang baik dengan anggota keluarga dan masyarakat disekitar anak akan mendorong anak untuk menjadi pribadi yang terbuka dan dapat menyesuaikan diri. Faktor selanjutnya yang dapat memberikan pengaruh pada NAM anak adalah emosi, pemuasan emosi yang dilakukan oleh lingkungan sekitar dapat mendorong perkembangan anak menjadi lebih stabil. Selain faktor lingkungan sosial dan emosi, yang dapat berpengaruh pada NAM anak adalah metode mendidik anak, dalam keluarga dan faktor rangsangan lingkungan baik di rumah maupun disekolah. Rangsangan lingkungan yang diberikan di lingkungan sekolah terutama di TKQ Riyadlushsibyan merupakan rangsangan yang mempunyai pengaruh yang sangat besar bagi perkembangan NAM anak, melalui motivasi serta rangsangan yang dilakukan guru dalam membimbing, mengajarkan dan mendidik anak dalam pembelajaran Al-Qur'an bisa dilakukan sesuai dengan tahap perkembangan anak (Amini \& Suyadi, 2020).

Berdasarkan uraian tersebut selama proses pembelajaran yang dilakukan di TKQ Riyadlushshibyan khsusnya yang berkaitan dengan pembelajaran Al-Qur'an pada anak usia 5-6 tahun, hal tersebut dapat mengembangkan aspek NAM, hal ini sesuai dengan Peraturan Menteri Pendidikan dan Kebudayaan Republik Indonesia nomor 146 tahun 2014, dimana anak sudah mampu (1) Mengenal agama yang dianutnya (anak mengetahui seorang muslimah harus menutup aurat); (2) anak mampu membiasakan diri untuk beribadah (anak sudah mampu melaksanakan shalat sunnah dhuha); (3) Anak mampu berperilaku sesuai dengan ajaran agama yang dianutnya (anak sudah mampu bersikap sopan, hormat, menghargai dan peduli); (4) Anak mampu menjaga kebersihan diri dan lingkungan; (5) Anak mengetahui hari besar agama (seperti hari raya idul fitri dan idul adha); dan (6) Aanak mampu menghormati atau toleransi terhadap agama lain (menghormati dalam bentuk anak mengetahui bahwa ada kitab lain selain Al-Qur'an). Hal tersebut dapat terwujud dan dapat diimplementasikan dengan bentuk pemahaman, pembiasaan, motivasi dan berbagai rangsangan yang dilakukan oleh guru kepada anak sedini mungkin melalui pengembangan membaca, menulis, dan menghafal Al-Qur'an sejak dini untuk mewujudkan peserta didik yang memiliki jiwa dan moralitas tinggi sesuai dengan nilai-nilai agama yang diajarkan. 


\section{SIMPULAN}

Implementasi pembelajaran Al-Qur'an terhadap perkembangan anak usia dini di Taman Kanak-Kanak Qur'an (TKQ) Riyadlushshibyan dilakukan dengan melibatkan tiga kemampuan yang diupayakan pengembangannya yakni kemampuan membaca, menulis, serta menghafal Al-Qur'an sejak dini. Pembelajaran Al-Qur'an yang dilaksanakan di sekolah mempunyai pengaruh besar dalam perkembangan Nilai Agama dan Moral (NAM) anak dimana dalam proses belajar mengajar Al-Qur'an di TKQ Riyadlushshibyan anak tidak hanya diajarkan membaca, menulis dan menghafal Al-Qur'an saja, tetapi juga diberi pemahaman dan penjelasan mengenai ayat yang mereka hafal dan anak diberi motivasi, rangsangan dan pembiasaan baik yang dilakukan secara berulang-ulang di sekolah.

\section{UCAPAN TERIMA KASIH}

Peneliti menghaturkan rasa syukur pada Allah悠, dan terima kasih pada semua pihak yang sudah ikut serta memberikan bantuannya kepada peneliti, terkhusus pada orang tua, dosen pengampu dan seluruh pihak Yayasan Riyadlushshibyan sejak tahap persiapan awal sampai terwujudnya laporan akhir penelitian ini.

\section{DAFTAR PUSTAKA}

Amini, N., \& Suyadi, S. (2020). Media Kartu Kata Bergambar Dalam Meningkatkan Kemampuan Kosakata Anak Usia Dini. PAUDIA : Jurnal Penelitian Dalam Bidang Pendidikan Anak Usia Dini, 9(2), 119-129. https:// doi.org/10.26877/paudia.v9i2.6702

Ardin, F. N., Indihadi, D., \& Rahman, T. (2020). Pengaruh Penggunaan Media Kartu Huruf Hijaiyah Menulis Pada Anak Usia Dini Di Ra Ath-Thoha Tasikmalaya. Jurnal Paud Agapedia, 4(1), 15-23. https:// doi.org/10.17509/jpa.v4i1.27193

Didik Supriyanto. (2015). Perkembangan Nilai Agama Dan Moral Anak. Perkembangan Nilai Agama Dan Moral Anak Dan Pendidikan Keagamaan Orangtua, 3(Maret), 1-20. http://jurnal.stitnualhikmah.ac.id/index.php/modeling/article/view/67 https:// doi.org/10.21831/jpa.v1i2.3018

Fitri, A. E. (2019). Perencanaan Pembelajaran Kurikulum 2013. Al - Azkiya: Jurnal Ilmiah Pendidikan MI/SD, 4(2), 112-122. https:// doi.org/10.32505/azkiya.v4i2.1191

Fowler, J. W., \& Dell, M. L. (2004). Stages of faith and identity: birth to teens. Child and Adolescent Psychiatric Clinics of North America, 13(1), 17-33. https:// doi.org/10.1016/S1056-4993(03)00073-7

Hidayat, B. (2017). Pembelajaran Alquran pada Anak Usia Dini Menurut Psikologi Agama dan Neurosains. Proceedings of The 2nd Annual Conference on Islamic Early Childhood Education, 2, 60.

Jahja, Y. (2011). Psikologi Perkembangan.

Julianto, T. A. (2020). Metode Menghafal dan Memahami al-Qur'an bagi anak usia dini melalui Gerakan Isyarat ACQ. IQRO: Journal of Islamic Education, 3(1), 71-84. http://ejournal.iainpalopo.ac.id/index.php/iqro/article/view/1439

Kebudayaan, K. P. dan. (2018). Pedoman Penyusunan Rencana Pelaksanaan Pembelajaran. 021.

Kementerian Pendidikan Nasional. (2014). Permendikbud No 146 Tahun 2014. 37), 33(8, بيب. http://paud.kemdikbud.go.id/wp-content/uploads/2016/04/Permendikbud-146Tahun-2014.pdf

Kuswanto, A. V. (2020). Mengembangkan Perkembangan Anak Usia Taman Kanak-Kanak. 4197.

https:// doi.org/10.26877/paudia.v9i2.6712

Lestariningrum, A. (2017). Buku Perencanaan Pembelajaran AUD. In Adjie Media Nusantara. Limbong, I., Munawar, M., \& Kusumaningtyas, N. (2019). Perencanaan pembelajaran paud berbasis steam (science, technology, eingeneering, art, mathematic). Seminar Nasional 
http://conference.upgris.ac.id/index.php/Snpaud2019/article/view/450

Mulyasa, H. E. (2012). Manajemen PAUD.

Nabil. (2017). Pendidikan Anak Usia Dini (PAUD) Dalam Pendekatan Psikologi Anak. Journal.Almarhalah.Ac.Id, 1(2). https:// doi.org/10.38153/alm.v1i2.9

Nabilah. (2019). Analisis Perkembangan Nilai Agama-moral Siswa Usia Dasar (tercapai) studi kasus di MI Ma'arif Bego. El-Ibtidaiy:Journal of Primary Education, 5-24. https://doi.org/10.24014/ejpe.v2i2.7954

Nasional, U. S. P. (2003). Undang-Undang Republik Indonesia Nomor 20 Tahun 2003 Tentang Sistem Pendidikan Nasional. 71, 6-6. https://doi.org/10.1111/j.16512227.1982.tb08455.x

Nurkhaeriyah. (2019). Metode Menghafal Alqur'an Pada Anak Usia Dini di Rumah Tahfidz Qur'an At-Taqwa Kota Cirebon. Jurnal Jendela Bunda, 7(1), 1-16. https://doi.org/10.25078/pw.v2i2.1007

Pangastuti, R. (2017). Pembelajaran Al-Quran Anak Usia Dini melalui Metode "'Wafa.'" Conference.Uin-Suka.Ac.Id, 2, 109-122. http://conference.uinsuka.ac.id/index.php/aciece/article/view/58

Primayana, K. H. (2019). Tantangan dan Peluang Dunia Pendidikan di Era 4.0. Prosiding Seminar Nasional Dharma Acarya, 1, 321-328.

Rahman, H., Rita Kencana, \& N. F. (2020). Pengembangan Nilai Moral dan Agama Anak Usia Dini Panduan Bagi Orang Tua, Guru, Mahasiswa, dan Praktisi PAUD.

Robert V. Kail, H. W. R. (2002). Advances In Child Development and Behavior Vol 29.

Srijatun, S. (2017). Implementasi Pembelajaran Baca Tulis al-Qur'an dengan Metode Iqra pada Anak Usia Dini di RA Perwanida Slawi Kabupaten Tegal. Nadwa: Jurnal Pendidikan Islam, 11(1), 25-42. https:// doi.org/10.21580/nw.2017.11.1.1321

Suyadi. (2013). Kepemimpinan Guru: Kepemimpinan Guru. Al-Bidayah, 6(1), 115-124. https://jurnal.albidayah.id/index.php/home/index

Umayah, S., \& Suyadi, S. (2020). Pengembangan Kurikulum Berbasis Nusantara dan Internasional di PAUD Fastrack Funschool Yogyakarta. JECED : Journal of Early $\begin{array}{llll}\text { Childhood Education } & \text { 1-12. }\end{array}$ https://doi.org/10.15642/jeced.v2i1.505

Wahyuni, M., Yuliantina, I., \& Ritayanti, U. (2018). Penyusunan Rencana Pelaksanaan Pembelajaran: Pendidikan Anak Usia Dini. Direktorat Pembinaan Pendidikan Anak Usia Dini, Kementrian Pendidikan Dan Kebudayaan, 021, 30. 